\title{
Quality Control of Sachet-Packaged Drinking Water Sold in Primary Schools and Dantokpa Market in Cotonou
}

\author{
Yemoa $A^{1 *}$, Mizehoun-Adissoda $C^{2}$, Bigot $C^{3}$, Kpohouenon $A^{2}$, Degbey $C^{4}$, Akotegnon $C^{5}$, Marini RD ${ }^{6}$, Balogoun $C^{5}$, \\ Zogo $\mathrm{D}^{5}$, Ake $\mathrm{M}^{7}$, Atindehou $\mathrm{E}^{7}$ and Bigot $\mathrm{A}^{3}$ \\ ${ }^{1}$ Laboratoire de Chimie Analytique et Analyse des Médicaments (LCAM), UFR Pharmacie, Faculté des Sciences de Santé de Cotonou, Université d'Abomey \\ Calavi, Bénin \\ 2.Ecole de Nutrition, Faculté des Sciences de Santé de Cotonou, Université d'Abomey Calavi, Bénin
}

${ }^{3}$ Faculté des Sciences de Santé de Cotonou, Université d'Abomey Calavi, Bénin

${ }^{4}$ Institut Régional de Santé Publique Comlan Alfred Quenum de Ouidah

${ }^{5}$ Société Nationale des Eaux du Bénin, Bénin

${ }^{6}$ Laboratory of Pharmaceutical Analytical Chemistry, CIRM, University of Liege (ULg), Liege, Belgium, Bénin

${ }^{7}$ Département de Chimie Analytique, Bromatologie, Chimie Minérale et Chimie Générale, UFR Sciences Pharmaceutiques et Biologiques - Université Félix Houphouët-Boigny, Côte d'Ivoire, Bénin

Submission: January 01, 2018; Published: January 26, 2018

*Corresponding author: Yemoa A, Université d'Abomey Calavi, Faculté des Sciences de Santé de Cotonou, Laboratoire de Chimie Analytique et Analyse des Médicaments (LCAM), 01 BP 494 Cotonou, Bénin, Tel: +229 970782 07; Email: ayemoa@yahoo.fr

Abstract

To assess the quality of sachet-packaged drinking water sold in primary schools and Dantokpa market in Cotonou (Benin), 44 samples were randomly selected from brands produced in Cotonou from November to December in 2017 for physico-chemical and bacteriological tests.

Eighteen (40.9\%) of 44 brands subjected to bacteriological examination contained staphylococci bacteria. Twenty three out of 44 brands (i.e. $52.3 \%$ ) examined also recorded the presence of common germs, and 9 (i.e. 20.5\%) exceeded the maximum permissible level of 50germs $/ \mathrm{mL}$. E. coli is found in one sample, the presumptive search for faecal streptococci is negative.

On the other hand, no deviation was recorded to the WHO and to the National drinking water quality guidelines for turbidity (5NTU), nitrates $(45 \mathrm{mg} / \mathrm{L})$, nitrites $(3 \mathrm{mg} / \mathrm{L})$, ammonium $(0.5 \mathrm{mg} / \mathrm{L})$. Two samples $(4.5 \%)$ failed to $\mathrm{pH}$ test according to same guidelines for $\mathrm{pH}(6.5-8.5)$. We noticed the absence of residual chlorine in all 44 samples submitted to chemical analyses.

Poor hygienic conditions during packaging, coupled with poor storage conditions and the absence of residual chlorine, might responsible for the presence of these germs in the waters concerned. There is a need for regulatory authorities to take appropriate measures in safeguarding public health.

Keywords : Sachet-packaged drinking water; Physico-chemical and microbiological tests; Drinking water quality standards; Primary schools/ Cotonou, Dantokpa market, Benin

\section{Introduction}

The Republic of Benin has an important population growth of nearly $3 \%$ and urban development in recent years counting $44.8 \%$ of the total population (2017) with an estimated urbanization rate of $3.55 \%$ per year (2015-2020) [1]. This development is one of the causes of the lifestyle change of citizens living in big cities. In recent years, this has led to the proliferation of sachet-packaged drinking water locally called "pure water" in Beninese cities, including Cotonou, the economic capital. This new category of drinking water is well appreciated by populations [2] because they are practical, refreshing, low cost and well presentable [3]. It is established that better access to safe drinking water can translate into tangible health benefits. But, water can also be the cause of diseases and cause of death [4].

Different sources of contamination are reported: faecal material, domestic and industrial sewage, agricultural and pasture run off [5]. Majority of health problems related to water result from microbiological contamination (bacteria, viruses, protozoa or others). However, chemical contamination of drinking water can also lead to a number of serious health issues. This is the case of methemoglobinemias for example with nitrites/nitrates. Due to the increased demand and 
consumption of sachet-packaged drinking water in low resources countries, there has been a growing interest about the quality of this vital product.

Various countries have enforced drinking water standards for the maximum permissible levels of different constituents and the WHO also edited guidelines for Drinking-water Quality [6].

By considering the guidelines, early studies conducted in Nigeria, Ghana, reported that the sachet-packaged samples of drinking water were of poor quality $[7,8]$. In Benin, the quality of sachet-packaged drinking water is not subjected to any stringent quality control measures. Hence the present study was made to analyze the microbial contamination, physical properties and chemical contents in different samples of sachet-packaged drinking water sold in Cotonou, namely in primary schools and Dantokpa market in comparison with the required WHO and national standards $[6,9]$.

\section{Materials and Methods}

\section{Study population and Sampling methodology}

Cotonou is the economic capital and the first city of Benin. It is a cosmopolitan city with a population of about 679,012 inhabitants in 2013 [10]. Cotonou is home to the country's largest economic, administrative and industrial infrastructure, which justifies a very high cost of living. Cotonou has 488 primary schools (public and private), and the international market of Dantokpa, the largest market in West Africa. These targets (market and school) were chosen as part of this study because they allow us to identify the maximum of "pure-water" brands marketed in Benin. Samples of "purewater" were collected between November to December 2017 in public primary schools and Dantokpa market according to a simple random sampling for analysis. Three sachets of each brand (0.5L sachet) were bought from vendors in each schools and at Dantokpa market. A total of 44 brand were collected.

\section{Materials}

The following materials were used: Mannitol salt phenol red agar for microbiology (Merck, Germany); Levine-EMB-Agar for the isolation and differentiation of $\mathrm{E}$. Coli and enterobacter (Merck, Germany); Membrane Filter enterococcus selective Table 1: Summary of physicochemical and microbiological results.

\begin{tabular}{|c|c|c|c|}
\hline Parameters & Sample (n=44) Number (\%) & WHO Standards per 100mL & National Standards per 100mL \\
\hline Common germs & & & \\
\hline Exceeding & $9(20.5 \%)$ & - & $50 / \mathrm{mL}$ \\
\hline No Exceeding & $35(79.5 \%)$ & & \\
\hline Total coliform & & & 0 \\
\hline Exceeding & $1(2.3 \%)$ & 0 & 0 \\
\hline No Exceeding & $43(97.7 \%)$ & & 0 \\
\hline E. Coli & & & \\
\hline Exceeding & $1(2.3 \%)$ & & \\
\hline
\end{tabular}

agar acc. to slanetz and bartley base for microbiology (Merck, Germany) enriched with chloride 2,3,5 triphenyl tetrazolium 1\% (Merck, Germany); Nutrient Agar N¹ (VWR Prolabo chemicals; Belgium); Cellulose Nitrate Filtrer $0,45 \mu \mathrm{m}$ (Sartorius stedim biotec; Germany); Combinart $\AA$ vacuum filtration systems for colony count and particle counting (Sartorius stedim biotec; Germany).

The Electrical Conductivity (EC) and temperature were measured with a conductivity meter HQ40d Multi $(\mathrm{HACH}$ Company, Loveland, Colorado, USA) for analysis. The $\mathrm{pH}$ values of the water samples were measured with a $\mathrm{pH}$ meter HQ $11 \mathrm{pH}(\mathrm{HACH})$. Turbidity were measured with a 2100 turbid meter (ISO Method 7027; HACH). ISO 7890 recommended spectrophotometer method and Zambelli reagent method were used to measure the nitrate and nitrite contents respectively $[6,7]$.

NFT 90-015 recommended spectrophotometer method was used to measure ammonium content. The spectrophotometer used was a HACH Lange DR 6000. Reagent method with O-Tolidine was used for residual chlorine.

\section{Quality control}

To ensure quality, water samples were transported and analyzed within 2-4 hours at arrival to the laboratory. Additionally, samples were analyzed using standard methods. Equipments were calibrated before use; a blank sample was included in each analysis. For physicochemical test, blank was constituted by distilled water. For microbial test, positive control was constituted by contaminate water analyzed before in our lab and sterilized distilled water was used as negative control.

\section{Results}

\section{Bacteriological of sachet-packaged drinking water}

As shown in Table 1, Out the 44 brands subjected to bacteriological examination, 18 (i.e. $40.9 \%$ ) samples contained staphylococci bacteria. 23 out of 44 samples (i.e. 53.3\%) examined also recorded the presence of common germs and 9 (i.e. 20.5\%) deviated from National Standard of 50 germs $/ \mathrm{mL}$. E. coli was found in 1 sample. All the samples showed negative growth for faecal streptococci. 


\section{Nutrition \& Food Science International Journal}

\begin{tabular}{|c|c|c|c|}
\hline No Exceeding & $43(97.7 \%)$ & & \\
\hline Staphylococci & & 0 & 0 \\
\hline Exceeding & $18(40.9 \%)$ & & \\
\hline No Exceeding & $26(59.1 \%)$ & & \\
\hline Faecal Streptococci & & 0 & 0 \\
\hline Exceeding & $0(00 \%)$ & & \\
\hline No Exceeding & $44(100.0 \%)$ & & \\
\hline Turbidity & & $5 \mathrm{NTU}$ & $5 \mathrm{NTU}$ \\
\hline Exceeding & $0(0.0 \%)$ & & \\
\hline No Exceeding & $44(100.0 \%)$ & & \\
\hline Conductivity & & - & - \\
\hline Exceeding & $0(0.0 \%)$ & & \\
\hline No Exceeding & $44(100.0 \%)$ & & \\
\hline Nitrates & & $45 \mathrm{mg} / \mathrm{L}$ & $50 \mathrm{mg} / \mathrm{L}$ \\
\hline Exceeding & $0(0.0 \%)$ & & \\
\hline No Exceeding & $44(100.0 \%)$ & & \\
\hline Nitrites & & $3.2 \mathrm{mg} / \mathrm{L}$ & $3 \mathrm{mg} / \mathrm{l}$ \\
\hline Exceeding & $0(0.0 \%)$ & & \\
\hline No Exceeding & $44(100.0 \%)$ & & \\
\hline Residual chlorine & & $0.2 \mathrm{mg} / \mathrm{mL}$ & $0.1 \mathrm{mg} / \mathrm{mL}$ \\
\hline Exceeding & $0(0.0 \%)$ & & \\
\hline No Exceeding & $0(0.0 \%)$ & & \\
\hline
\end{tabular}

Note that measuring "Residual chlorine" is as important as the presence of chlorine residual in water indicates that (i) a sufficient amount of chlorine was added initially to the water to inactivate the bacteria and some viruses that can cause diarrheal diseases, and (ii) the water is protected from recontamination during storage.

\section{Physicochemical quality of sachet-packaged drinking water}

Electric Conductivity content of the 44 different samples of drinking water samples varied from 38.8 to $216.8 \mu \mathrm{S} / \mathrm{cm}$ (mean value was $146.6( \pm 49.0) \mu \mathrm{S} / \mathrm{cm}$ ). The temperature values of the 44 different samples varied from $25.0^{\circ} \mathrm{C}$ to $27.4{ }^{\circ} \mathrm{C}$ with the mean of $26.2( \pm 0.7){ }^{\circ} \mathrm{C}$. No recommendation was found in National Standards for these two parameters. The $\mathrm{pH}$ values of the 44 different samples varied from 6.37 to 7.02 and two samples failed to the pH test (the recommendation is 6.5 to 8.5) [7]. The turbidity of samples were within the acceptable range ( $<5 \mathrm{NTU}$ ) and varied from 0.261 to $3.32 \mathrm{NTU}$.

Apart from the residual chlorine, for which we noticed total absence in all 44 samples; no deviation was recorded to the maximum permissible limits with the following measured chemical parameters: Nitrates: $2.1-3.6 \mathrm{mg} / \mathrm{L}$, Nitrites: $<0.046 \mathrm{mg} / \mathrm{L}$ and Ammonium: $<0.05 \mathrm{mg} / \mathrm{L}$ ) which were within the WHO and National drinking water requirements. Table 1

\section{Discussion}

The physical chemical and bacteriological state of packaged water is a very important aspect that should be observed by all the packaging companies.

Sachet-packaged drinking water is well appreciated by populations in some African countries such as Benin because they are practical, refreshing, low cost and well presentable $[2,3]$. It must be verified whether these waters meet the required standards of quality and regulations in Benin and therefore whether they do not constitute a public health concern.

As per the national and WHO standards, drinking water should have turbidity of less than $5 \mathrm{NTU}$, pH range of 6.5-8.5, and total coliform and faecal coliform of 0.00 per $100 \mathrm{~mL}$. As a measure for safety, indicator organisms of coliforms are investigated and their presence generally indicates that the water may contain disease causing agents. Coliforms are in two categories: total (all) coliforms count which indicates general contamination and faecal coliform count which indicates faecal contamination and is a significant indicator of pollution [11]. E. coli is found in one sample of 44 tested (2.3\%), the presumptive search for faecal streptococci is negative. The similar result was found in another study in Nigeria in Oke-Iho and Okaka cities (representing 2.2\% of total samples).

The Staphylococci contamination is the most prevalent the analyzed samples (i.e. $40.9 \%$ ). Staphylococcus is a type of bacteria commonly found on the skin and hair as well as in the noses and throats of people and animals. Staphylococcus can cause water poisoning when a water handler contaminates water. Other sources of water contamination can include the equipment and sachet in which water is packaged. These 
bacteria multiply quickly at room temperature to produce a toxin that causes illness. Staphylococcus is killed by cooking (boiling) and pasteurization. But in our case, the water is drinked directly without prior boiling. Poor hygienic conditions during packaging, coupled with poor storage conditions and the absence of residual chlorine, might responsible for the presence of these germs in the analyzed samples. Hence, there is a need for strict regulations in ensuring among others the quality of drinking water in the frame of protecting the public health.

Then, the following recommendations are made for the sachet water handler:

o Thoroughly wash hands and under fingernails with soap and water before handling and packaging the water;

o Not handling and packaging water in case of sickness of nose, eyes, skin, etc. that may contaminate the water to drink;

o Maintain the overall cleanliness of premises, production equipment and packaging materials as well as the hygiene of all staff involved in the production or sale of the drinking water;

o Seek for technical advice and guidance from competent public health authorities to ensure that the drinking water complies with the required quality standards.

In general, the high quality claimed for sachet waters could not be confirmed, based on the results of physico-chemical and bacteriological parameters measured. The poor water quality observed reflects the fact that the sachets are not always bagged under scrutinized sanitary conditions; it is also confirmed by studies conducted in Ghana, Nigeria and Uganda $[8,11]$.

Based on the WHO recommended maximum tolerable levels of contaminants, and national Quality and Standards Authority of Benin, around $47.7 \%$ ( 1 for $\mathrm{pH} ; 20$ for bacterial contaminants) of sachet-packaged drinking water commercially sold could be considered unfit for human consumption as far as the tested parameters in this study were found out-of-specifications. All samples seem to present a risk of contamination due to the total absence of residual chlorine, and consumers of this category of water should be aware of this, but also the sellers and producers must be sensitized and take appropriate measures to comply with the quality requirements.

\section{Conclusion}

It can be concluded from the results of this preliminary study that around $47.7 \% \%$ of the sachet-packed water sold in public primary schools and Dantokpa market in Cotonou (Benin) were of poor quality.

The majority of sachet water samples were contaminated with staphylococcus bacteria, and the current findings lead to call Beninese Regulatory authorities to take appropriate measures in monitoring the quality of drinking water in general, and particularly the popular water packed in sachets to safeguard public health. A wider study should be conducted according to same rules of good practice for a more complete analysis of the situation.

\section{References}

1. Benin's population (2018).

2. Ble LO, Soro TD, Dje KB, Degny GS, Biemi J (2015) Eaux conditionnées en sachets: quels risques d'exposition des populations du district d'Abidjan? Larhyss Journal, ISSN 1112-3680, n²4: 85-107.

3. Aboli AT, Manizan NP, Kacou-Ndouba A, Dosso M (2007) Evaluation du risque sanitaire des eaux en sachet plastique vendues dans la ville d'Abidjan (côte d'ivoire). Revue Bio-Africa - Numero Special, pp. 57-63

4. OMS (2003) Année internationale de l'eau douce, faits et chiffres, les maladies liées à l'eau.

5. Zgheib S (2009) Flux et sources des polluants prioritaires dans les eaux urbaines en lien avec l'usage du territoire. thèse de Docteur de l'école nationale des ponts et chaussée, école des ponts Paris tech, France, pp. 360.

6. OMS (2017) Directives de qualité pour l'eau de boisson, ( $4^{\text {th }}$ édn), intégrant le premier additive, pp. 564.

7. Olaoye OA, Onilude AA (2009) Assessment of microbiological quality of sachet-packaged drinking water in Western Nigeria and its public health significance. Public Health 123(11): 729-734.

8. Dodoo DK, Quagraine EK, Okai-Sam F, Kambo DJ, Headley JV (2006) Quality of "sachet" waters in the Cape Coast municipality of Ghana. J Environ Sci Health A Tox Hazard Subst Environ Eng 41(3): 329-342.

9. Decret N²001-094 du 20 février 2001 fixant les normes de qualité de l'eau potable en République du Bénin.

10. Ministère du Développement, de l'Analyse Economique et de la Prospective/ Institut National de Statistique et de l'Analyse Economique (2015): RGPH4 que retenir des effectifs de population en 2013 ? pp. 33

11. Ali Halage A, Ssemugabo C, Ssemwanga DK, Musoke D, Mugambe RK, et al. (2015) Bacteriological and Physical Quality of Locally Packaged Drinking Water in Kampala, Uganda. Journal of Environmental and Public Health, Article ID 942928, p. 1-6. 
This work is licensed under Creative Commons Attribution 4.0 License DOI: $10.19080 / \mathrm{NFSIJ} .2018 .04 .555649$

\section{Your next submission with Juniper Publishers will reach you the below assets}

- Quality Editorial service

- Swift Peer Review

- Reprints availability

- E-prints Service

- Manuscript Podcast for convenient understanding

- Global attainment for your research

- Manuscript accessibility in different formats ( Pdf, E-pub, Full Text, Audio)

- Unceasing customer service

Track the below URL for one-step submission https://juniperpublishers.com/online-submission.php 